\title{
Immune Complexes-Like Disease in the Course of Enterobacter cloacae sepsis Due to Cholelithic Cholecystitis, Preceded by Influenza Vaccination
}

Sławomir Tubek ${ }^{1 *}$, Józef Bojko ${ }^{2}$, Magdalena Żurek ${ }^{1}$, Krzysztof Kamiński ${ }^{3}$, Marek Szymkowicz ${ }^{3}$, Janusz Pichurski ${ }^{4}$ and Renata Szyguła ${ }^{5}$

1 Internal Medicine Ward of the Voivedship Hospital in Opole, Poland

${ }^{2}$ Anestesiology and Intensive Care Ward of the Voivedship Hospital in Opole, Poland

${ }^{3}$ Surgery Ward of Regional Hospital in Nysa, Poland

${ }^{4}$ Surgery Ward of the Voivedship Hospital in Opole, Poland

${ }^{5}$ Department of Pysiotherapy and Physical Education, Technical University in Opole, Poland

\begin{abstract}
Summary
The authors present a case of a male who, a week after influenza vaccination presented with abdominal symptoms - pain in the right epigastrium followed by pyrexia, muscle pain, disturbed liver and kidneys function as well as consciousness disorders. Immune complex-like disease and Enterobacter cloacae sepsis due to cholelithic cholecystitis were diagnosed. In this case, the suspected correlation between vaccination and immune complex-like disease resulted mainly from two reasons-the onset of symptoms after few days after vaccinations and clinical improvement after plasmaferesis. In etiopathogenesis of this specific case the similar immunogenicity of vaccine compounds and Enterobacter cloacae antigens, and patient genetic predisposition should be considerated.
\end{abstract}

\section{Description}

A patient (52), with previous history of arterial hypertension, reported to the Emergency Room due to fever up to $39^{\circ} \mathrm{C}$ for seven days accompanied by headache, vomiting and jaundice. From the onset of the symptoms he took oral clarithromycin with no improvement, and then was switched to amikacin intramuscularly. He also reported passing dark urine and fits of dry cough, denied alcohol or paracetamol overdose. He ate mushrooms seven days prior to admittance. A week before the onset of the disease he had flu vaccination. No foreign travels over the last year. One year history of discomfort in the right epigastrium.

Physical examination revealed excessively warm skin, jaundice, tenderness to palpation in the right epigastrium with positive Chełmoński sign, no peritoneal signs. Allopsychic orientation incomplete - patients showed defects of the fresh memory.

Lab tests showed increased activity of aminotransferases (AST 3004 $\mathrm{U} / \mathrm{l}$, ALT $4182 \mathrm{U} / \mathrm{l})$, elevated concentration of bilirubin $(8,3 \mathrm{mg} / \mathrm{dl})$ with direct bilirubin prevalence $(7,75 \mathrm{mg} / \mathrm{dl})$, GGT $(162 \mathrm{U} / \mathrm{l})$, creatinine (3,08 $\mathrm{mg} / \mathrm{dl})$, CPK $(603 \mathrm{U} / \mathrm{l})$, procalcitonine $(3,65 \mathrm{ng} / \mathrm{ml})$, ferritine $(>100.000 \mathrm{ng} / \mathrm{ml})$, d-dimers $(6,52 \mu \mathrm{g} \mathrm{FEU} / \mathrm{ml})$, depleted number of platelets $\left(75 \times 10^{3} / \mu \mathrm{l}\right)$ and leucocytes $\left.2,81 \times 10^{3} / \mu \mathrm{l}\right)$ as well as normal values of INR [1,2], albumins (3,2 g/dl) and CRP (3,86-5,11 mg/l). Tests for hepatotropic viruses (HBs, HCV and CMV) were negative. The repeated abdominal ultrasound showed evidence of an acute cholelithic cholecytitis, and small amount of free liquid in the peritoneum and around the gall bladder. The cardiac ultrasound was normal. Toxic injury of the liver (paracetamol, occupational factors - work in a car service) was ruled out. The impact of the vaccination was taken into consideration. The blood culture was positive for Enterobacter cloacae. Patient received an antibiotic according to the antibiogram.

Regarding the whole course of the disease, with unproportionally increased biochemical parameters and relatively good general condition of the patient and well preserved liver function as well as a two fold decrease in amintransferases activity after administration of i.v. steroids for initially suspected toxic defect, a suspicion of septicaemia with immune complexes disease was stated. Regarding the surgeon's consultation, after three days in the Medical Ward the patient was transferred to the Surgery Department for surgery of the cholelithic cholecystitis.
The gall bladder with some inflammatory infiltration was removed and Kehr's drain was implemented into the normal biliary duct, which runs no bile. In the course of the operation cholelithic cholecystitis was confirmed with hard, infiltrated liver and liver hilar lymphadenopathy. The patient was stable during the procedure with no cardio- pulmonary incidents but after the surgery prolonged respiratory insufficiency occured.

After the procedure patient was transferred to Intensive Care Unit. During his stay in the unit-apart from standard therapy-plasmaferesis was performed for three consecutive days, leading to gradual normalization of the renal and hepatic function excluding cholestatic parameters, with increase in GGT (482 U/l) and bilirubin $(14 \mathrm{mg} / \mathrm{dl})$, direct bilirubin prevailing.

The general condition of the patient and his cardio-respiratory function gradually improved, biliary leaks receded (cholangiography via Kehr's drain, abdominal CT scan) as did the cholestasis (bilirubin $7,0 \mathrm{mg} / \mathrm{dl}$ ). The patient was transeferred to the General Surgery Department in Nysa. By that time the biliary duct prosthesis was endoscopically inserted and the duct was decompressed. During the stay fever reoccured with no laboratory deterioration - due to subphrenic abscesses that required reoperation.

The patient recovered totally, after 8 weeks the prosthesis was removed, lab tests normal. During the disease his weight fell by $11 \mathrm{~kg}$.

\section{Discussion}

The probable initial causal factor for the pyrexia was an exacerbation

*Corresponding author: Sławomir Tubek, Internal Medicine Ward of the Voivedship Hospital in Opole, Kośnego Street 53, Opole 45-372, Poland, E-mail: slawomir.tubek@hipokrates.org

Received April 16, 2011; Accepted May 18, 2011; Published May 20, 2011

Citation: Tubek S, Bojko J, Żurek M, Kamiński K, Szymkowicz M, et al. (2011) Immune Complexes-Like Disease in the Course of Enterobacter cloacae sepsis Due to Cholelithic Cholecystitis, Preceded by Influenza Vaccination. J Vaccines Vaccin 2:119. doi:10.4172/2157-7560.1000119

Copyright: ( 2011 Tubek S, et al. This is an open-access article distributed unde the terms of the Creative Commons Attribution License, which permits unrestricted use, distribution, and reproduction in any medium, provided the original author and source are credited. 
Citation: Tubek S, Bojko J, Żurek M, Kamiński K, Szymkowicz M, et al. (2011) Immune Complexes-Like Disease in the Course of Enterobacter cloacae sepsis Due to Cholelithic Cholecystitis, Preceded by Influenza Vaccination. J Vaccines Vaccin 2:119. doi:10.4172/2157-7560.1000119

Page 2 of 2

of the chronic cholecystitis, although due to oral antibiotic therapy it's symptoms could have been uncharacteristic.

On admission patient presented with symptoms of immune complexes-like disease and multiorgan injury that initially masked the signs of cholecystitis.

At the beginning the toxic causes (paracetamol, fungi, occupational factors) or the the influenza vaccination were taken into consideration. Although, inadequatly high activity of aminotransferases compared to normal liver function (e.g. normal INR) and renal defect as well as improvement of general condition and biochemical parameters after administration of steroids led to diagnosis of sepsis with a starting point in the gall bladder, complicated by immune complexes disease. Blood cultures showed Gram negative bacteria Enterobacter cloacae and significant improvement in the postoperative period was achieved after plasmaferesis.

The Gram negative bacteriemia with onset in the abdominal cavity may lead to immune complexes disease with crescentic glomerulonephritis [1] which could occur in the reported case. The occurence of immune complexes during sepsis has been described in literature $[2,3]$.

Theoretically three options can be considered:

1. The influenza vaccination could have induced the immune complexes-like disease in course of which an exacerbation of chronic cholecystitis occured.

2. The influenza vaccination induced an exacerbation of chronic cholecystitis followed by septicaemia and immune complexes-like disease.

3. Casual coincidence of vaccination and the exacerbation of cholecystitis followed by septicaemia and immune complexes-like disease in it's course.

The question about the initiating factor - be it vaccination inducing the immune complexes-like or cholecystitis with immune complexeslike disease in the course of sepsis - will remain unanswered. Regarding the fact that flu vaccination can be complicated by serum sickness or serum sickness-like disease $[4,5,6]$, the impact of the vaccination on the clinical course of the reported case cannot be ruled out. The possibility of serum sickness symptoms occurrence after another vaccinations is reported in literature [6-15]. Immune complex deposition and adjuvant effects are potential pathogenic mechanisms of such immune complexlike diseases $[8,16,17]$.

In this case, the suspected correlation between vaccination and immune complex-like disease resulted mainly from two reasonsthe onset of symptoms after few days after vaccinations and clinical improvement after plasmaferesis. In etiopathogenesis of this specific case the similar immunogenicity of vaccine compounds and Enterobacter cloacae antigens [18], and patient genetic predisposition [19] should be considerated.

\section{References}

1. Janette JC (2003) Rapidly progressive crescentic glomerulonephritis. Kidney Int 63: 1164-1177.

2. Young LS, Stevens P, Kaijser B (1982) Gram-negative pathogens in septicaemic infections. Scand J Infect Dis Suppl. 31: 78-94.

3. Rao VP, Poutahidis T, Marini RP, Holcombe H, Rogers AB, et al. (2006) Renal infarction and immune-mediated glomerulonephritis in sheep (Ovis aries) chronically implanted with indwelling catheters. J Am Assoc Lab Anim Sci 45 : 14-19.

4. Apisarnthanarak A, Uyeki TM, Miller ER, Mundy LM (2009) Serum sickness-like reaction associated with inactivated influenza vaccination among Thai health care personnel: risk factors and outcomes. Clin Infect Dis 49: e18-22.

5. Ehrengut W, Allerdist $H$ (1977) Neurological complications after influenza vaccination (author's transI). MMW Munch Med Wochenschr 119: 705-710.

6. Altman A, Szyper-Kravitz M, Shoenfeld Y (2008) HBV vaccine and dermatomyositis: is there an association? Rheumatol Int 28: 609-612.

7. Mall T, Gyr K (1984) Episode resembling immune complex disease after cholera vaccination. Trans R Soc Trop Med Hyg 78: 106-107.

8. Fraunfelder FW, Suhler EB, Fraunfelder FT (2010) Hepatitis B vaccine and uveitis: an emerging hypothesis suggested by review of 32 case reports. Cutan Ocul Toxicol 29: 26-29.

9. Hengge UR, Scharf RE, Kroon FP, Pfeffer K (2006) Severe serum sickness following pneumococcal vaccination in an AIDS patient. Int J STD AIDS 17 210-211.

10. Laribière A, Miremont-Salamé G, Reyre H, Abouelfath A, Liège L, et al. (2005) Surveillance of adverse effects during a vaccination campaign against meningitis C. Eur J Clin Pharmacol 61: 907-911.

11. Geier MR, Geier DA (2004) A case-series of adverse events, positive re-challenge of symptoms, and events in identical twins following hepatitis B vaccination: analysis of the Vaccine Adverse Event Reporting System (VAERS) database and literature review. Clin Exp Rheumatol 22: 749-755.

12. Wise RP, Iskander J, Pratt RD, Campbell S, Ball R, et al. (2004) Postlicensure safety surveillance for 7 -valent pneumococcal conjugate vaccine. JAMA 292 $1702-1710$.

13. Arkachaisri $T$ (2002) Serum sickness and hepatitis $B$ vaccine including review of the literature. J Med Assoc Thai 85 Suppl 2: S607-612.

14. Graham LE (2001) Postvaccination serum sickness with de Quervain's tenosynovitis. Rheumatol Int 20: 251-252.

15. Warrington RJ, Martens CJ, Rubin M, Rutherford WJ, Aoki FY (1987) Immunologic studies in subjects with a serum sickness-like illness after immunization with human diploid cell rabies vaccine. J Allergy Clin Immunol 79: 605-610.

16. Shoenfeld Y, Agmon-Levin N (2011) 'ASIA' - autoimmune/inflammatory syndrome induced by adjuvants. J Autoimmun. 36: 4-8.

17. Satoh M, Bjerkås I, Haugarvoll E, Chan EK, Szabo NJ, et al. (2011) Polyclona hypergammaglobulinemia and autoantibody production induced by vaccination in farmed Atlantic salmon. Fish Shellfish Immunol 30: 1080-1086.

18. Woo PC, Wong LP, Zheng BJ, Yuen KY (2001) Unique immunogenicity of hepatitis $B$ virus DNA vaccine presented by live-attenuated Salmonella typhimurium. Vaccine 19: 2945-2954.

19. Münz C, Lünemann JD, Getts MT, Miller SD (2009) Antiviral immune responses: triggers of or triggered by autoimmunity? Nat Rev Immunol 9: 246-258. 